Vol. 1 No. 2 September 2021, e-ISSN : 2797-8842 | p-ISSN : 2797-9431

\title{
ANALISIS KESULITAN BELAJAR SISWA PADA MATERI PERSAMAAN DASAR AKUNTANSI KELAS XII IPS-1 DI SMA NEGERI 1 CANDIROTO
}

\author{
NUR TUTI HARIYANTI \\ SMA Negeri I Candiroto
}

Email : Nurtuti98@gmail.com

\begin{abstract}
ABSTRAK
Penelitian ini bertujuan untuk memberikan gambaran mengenai kesulitan belajar siswa pada materi persamaan dasar akuntansi kelas XII IPS 1 di SMA Negeri 1 Candiroto Kabupaten Temanggung. Metode penelitian yang digunakan adalah pendekatan kualitatif. Sampel penelitian ini adalah satu kelas dengan jumlah 32 siswa. Hasil penelitian menunjukkan bahwa siswa sulit dalam menentukan akun dan sulit menentukan jumlah nominal dari akun yang dimaksud. Faktor-faktor yang menyebabkankesulitan dalam belajar antara lai : terganggunya kesehatan siswa ketika belajar, motivasi belajar yang rendah, minat belajar siswa terhadap pembelajaran akuntansi tergolong rendah, sikap yang ditunjukkan siswa ketika belajar masih kurang baik, cara mengajar guru dianggap kurang menyenangkan, sumber belajar (buku pelajaran) minim. Usaha-usaha yang dilakukan oleh guru untuk mengatasi kesulitan belajar siswa adalah dengan memotivasi siswa, berupaya untuk menumbuhkan minat siswa terhadap pelajaran yang dipelajari, memberikan evaluasi pada setiap pembelajaran, mengadakan remedial, dan menyuruh siswa agar lebih rajin dalam membaca dan mengulang kembali materi dirumah.
\end{abstract}

Kata kunci: Kesulitan belajar dan persamaan dasar akuntansi

\section{PENDAHULUAN}

Dalam kegiatan pembelajaran terkadang dijumpai adanya peserta didik yang mengalami kesulitan dalam mencapai standar kompetensi dan kompetensi dasar yang telah ditentukan. Secara umum kesulitan belajar yang dihadapi siswa bukan hanya pada mata pelajaran eksak saja. Mata pelajaran yang bersifat sosial pun terkadang mendatangkan kesulitan bagi siswa seperti mata pelajaran ekonomi khususnya pada pokok bahasan akuntansi yang dipelajari di kelas XII. Bagi sebagian siswa, materi akuntansi biasanya dijadikan sesuatu yang sulit, karena tingkat kesulitan mempelajarinya lebih tinggi dibandingkan dengan ilmu-ilmu sosial yang lain sebab materi akuntansi berhubungan dengan angka-angka yang menuntut ketelitian tinggi.

Bahwa Pembelajaran Akuntansi merupakan suatu proses kerjasama antara guru dan siswa untuk mendapatkan ilmu tentang bagaimana mengelola informasi keuangan yang sesuai dengan tujuan yang telah ditentukan. Pembelajaran Akuntansi di SMA N 1 Candiroto diajarkan sesuai dengan Kriteria Ketuntasan Minimal KKM yang tercantum dalam Kurikulum Tingkat Satuan Pendidikan Kurikulum 13 yang disesuaikan dengan kondisi di SMA Negeri 1 Candiroto Tahun Ajaran 2021-2022.

Menurut American Accounting Association (AAA) menjelaskan bahwa akuntansi adalah proses mengidentifikasikan, mengukur, dan melaporkan informasi ekonomi, untuk memungkinkan adanya penilaian dan keputusan yang jelas dan tegas bagi mereka yang menggunakan informasi tersebut. Di Sekolah Menengah Atas akuntansi termasuk ilmu sosial yang wajib dipelajari.

Fungsi pembelajaran akuntansi di SMA adalah untuk mengembangkan pengetahuan, keterampilan, sikap rasional, teliti, jujur dan bertanggung jawab melalui prosedur pencatatan, pengelompokkan, pengikhtisaran transaksi keuangan yang terjadi selama periode pembukuan. Adapun tujuan mempelajari akuntansi di sekolah adalah untuk membekali siswa dengan berbagai kompetensi dasar. Dengan berbagai kompetensi tersebut siswa diharapkan mampu menguasai dan menerapkan konsep-konsep dasar dan prosedur akuntansi yang benar, baik untuk kepentingan melanjutkan pendidikan ke perguruan tinggi maupun untuk terjun ke dalam 
masyarakat yang diharapkan bisa memberikan manfaat bagi kehidupan siswa dan masyarakat disekitarnya

Pada proses pembelajaran, guru sebagai pengajar sekaligus memegang peranan dan tanggung jawab yang besar dalam meningkatkan keberhasilan peserta didik. Salah satu parameter yang digunakan untuk mengukur tingkat keberhasilan siswa dalam proses belajar, yaitu hasil belajar yang umumnya ditunjukkan dalam bentuk nilai. Hasil belajar adalah kemampuan yang diperoleh anak setelah melalui kegiatan belajar (Hasbullah 2010:37).

Pada pembahasan akuntansi salah satu materi yang akan dibahas adalah tentang sistem persamaan dasar akuntansi. Materi tersebut merupakan materi awal dari pokok bahasan akuntansi. Permasalahan dalam proses pembelajaran akan menyebabkan rendahnya hasil belajar yang dicapai oleh siswa kurang maksimal. Dalam satu kelas dengan jumlah rata-rata 32 siswa, yang dapat menganalisa bukti transaksi kurang dari 40\%, sehingga masih banyak siswa yang belum mencapai nilai batas ketuntasan minimal. Maka dari itu saya ingin meneliti apa saja yang menyebabakan siswa mengalami kesulitan dalam menganalisa transaksi. Persamaan dasar akuntansi diartikan sebagai catatan tentang perubahan unsur-unsur dasar posisi keuangan perusahaan ( aset, liabilitas, dan ekuitas) akibat dari adanya transaksi. Persamaan dasar akuntansi dapat ditentukan dengan rumus:

$$
\text { Aset }=\text { Liabilitas }+ \text { Ekuitas }
$$

Dari hasil evaluasi tugas siswa kelas XII IPS-1 yang kumpulkan SMA Negeri 1 Candiroto menunjukkan bahwa masih banyak siswa yang mendapatkan nilai dibawah standar ketuntasan minimal (KKM). Jumlah keseluruhan 34 siswa yang tidak tuntas pada materi persamaan dasar akuntansi, yaitu 20 siswa. Bertitik tolak pada data yang ada, peneliti menjadi tertarik untuk meneliti tentang "Analisis Kesulitan Belajar Siswa Pada Materi Persamaan Dasar Akuntansi Kelas XII IPS-1 SMA Negeri 1 Candiroto". Untuk mengetahui tentang kesulitankesulitan yang dihadapi dalam menganalisis transaksi pada materi persamaan dasar akuntansi dan faktor-faktor penyebab timbulnya kesulitan. Adapun kesulitan belajar yang dihadapi oleh siswa dalam mengalisa bukti transaksi ada beberapa faktor, antara lain : terganggunya kesehatan siswa ketika belajar, motivasi belajar yang rendah, minat belajar siswa terhadap pembelajaran akuntansi tergolong rendah, sikap yang ditunjukkan siswa ketika belajar masih kurang baik, cara mengajar guru dianggap kurang menyenangkan, sumber belajar (buku pelajaran) minim.

Oemar Hamalik (dalam Sumarti Dewiyani : 27-28), faktor penyebab kesulitan belajar adalah faktor yang bersumber dari diri siswa sendiri antara lain kurangnya minat terhadap belajar dan kesehatan yang terganggu, sikap belajar, faktor yang bersumber dari lingkungan keluarga antara lain kemampuan ekonomi keluarga dan kurangnya kontrol keluarga, faktor yang bersumber dari lingkungan sekolah antara lain cara guru mengajar dan kurangnya sumber (buku pelajaran), faktor yang bersumber dari lingkungan masyarakat antara lain bekerja sambil sekolah dan aktivitas organisasi.

Ahmadi dan Supriyono (2013: 78) menyatakan bahwa "faktor- faktor penyebab kesulitan belajar dapat digolongkan menjadi dua golongan, yaitu faktor intern (faktor dari dalam diri manusia itu sendiri) dan faktor ekstern (faktor dari luar manusia)". faktor intern meliputi faktor faktor fisiologi dan faktor psikologi. Sedangkan faktor ekstern meliputi faktor keluarga, faktor sekolah dan faktor mass media dan lingkungan sosial.

\section{METODE PENELITIAN}

Metode penelitian yang digunakan adalah pendekatan kualitatif. Penelitian ini dilakukan di SMA Negeri 1 Candiroto Temanggung. Siswa yang menjadi subjek penelitian adalah siswa kelas XII IPS-1 yang mengalami kesulitan belajar pada materi persamaan dasar akuntansi. Siswa kelas tersebut berjumlah 34 siswa yang terdiri dari siswa laki-laki 11 orang dan siswa perempuan 23 orang dengan sampel penelitian adalah 20 orang siswa. Waktu penelitian selama satu bulan dimulai dari bulan Agustus minggu pertama sampai dengan minggu ketiga. Teknik penarikan sampel yang digunakan adalah non probability sampling, 
yaitu dengan menggunakan snowball sampling. Snowball sampling adalah teknik penentuan yang mula-mula jumlahnya kecil, kemudian membesar. Kami melakukan wawancara dengan siswa-siswi kelas XII IPS-1 yang mengalami kesulitan belajar pada materi persamaan dasar akuntansi dan wawancara dihentikan ketika telah sampai pada data yang diinginkan. Setelah mendapat jawaban yang tidak bervariasi /relatif sama dalam setiap pertanyaan yang diajukan kepada siswa. Wawancara dilakukan secara acak dan dihentikan setelah melakukan wawancara terhadap 20 orang siswa karena telah mencapai data yang cukup.

Teknik pengumpulan data yang digunakan dalam penelitian adalah teknik komunikasi langsung dan teknik studi dokmenter. Teknik komunikasi langsung dilakukan dengan cara mewawancarai siswa kelas XI IPS-1 yang mengalami kesulitan belajar pada materi persamaan dasar akuntansi dan guru mata pelajaran ekonomi lalu mendokumentasikan kegiatan penelitian ke dalam bentuk foto atau gambar dari kegiatan proses penelitian. Alat pengumpul data yang digunakan berupa pedoman wawancara dan kertas kerja dokumentasi.

Dalam menganalisis data yang telah diperoleh melalui wawancara peneliti menggunakan teknik analisis domain. Lexy J. Moleong (2013 : 305), mengemukakan bahwa analisis domain dilakukan terhadap data yang diperoleh dari pengamatan berperanserta/ wawancara atau pengamatan deskriptif yang terdapat dalam catatan lapangan.Adapun langkahlangkah yang digunakan dalam menganalisis data, yaitu (1) mengumpulkan data melalui wawancara dan dokumentasi, (2) melakukan pemeriksaan secara mendalam terhadap data yang sudah terkumpul, (3) menganalisis data yang sudah terkumpul, (4) membuat kesimpulan berdasarkan data yang sudah terkumpul.

\section{HASIL DAN PEMBAHASAN}

\section{Hasil}

Yang menjadi subyek utama dalam penelitian ini adalah siswa kelas XI IPS-1 yang mengalami kesulitan belajar pada materi persamaan dasar akuntansi. Data yang pksaya sajikan pada penelitian ini merupakan data hasil wawancara dengan informan kelas XI IPS yang berjumlah 34 siswa melalui penelitian yang telah dilakukan di SMA Negeri 1 Candiroto Temanggung. Wawancara dilakukan selama 2 hari, dimulai pada tanggal 1 Agustus 2021 dan dilanjutkan kembali pada tanggal 10 Agustus 2021.

1. Kesulitan yang dihadapi dalam menganalisis transaksi.

Berdasarkan hasil wawancara yang telah dilakukan terhadap siswa diketahui bahwa yang menjadi kendala bagi siswa ketika menganalisis transaksi pada materi persamaan dasar akuntansi terdiri atas dua kendala, yaitu siswa sulit untuk menentukan akun dan sering salah dalam menetukan jumlah nominal dari akun yang dimaksud. Kedua hal ini pada akhirnya menyebabkan hasil yang diperoleh dari persamaan dasar akuntansi menjadi tidak seimbang. Sesuai dengan pendapat Agung Feryanto dkk (2012:20), menyatakan bahwa persamaan akuntansi merupakan dasar pencatatan akuntansi dengan sistem berpasangan. Oleh sebab itu, kedua sisi yang saling berpasangan harus seimbang dalam menunjukkan setiap transaksi yang terjadi beserta perubahannya. Dengan demikian apabila hasil dari persamaan dasar akuntansi tidak seimbang, maka dapat disimpulkan bahwa pekerjaan siswa dalam menyelesaikan soal persamaan dasar akuntansi tersebut salah. Berdasarkan hasil temuan di atas dapat disimpulkan bahwa siswa mengalami kesulitan belajar pada pokok bahasan akuntansi karena kurangnya pemahaman terhadap materi yang dijelaskan sehingga menyebabkan hasil belajar yang diperoleh menjadi tidak dapat mencapai kriteria ketuntansan minimal yang telah ditetapkan oleh sekolah, yaitu 75. Hal tersebut sesuai dengan pendapat Abin Syamsuddin Makmun (2012:308), yang menyatakan bahwa seseorang diduga mengalami kesulitan belajar kalau yang bersangkutan tidak mencapai taraf kualifikasi hasil belajar tertentu. 
2. Faktor-faktor yang menyebabkan kesulitan belajar

a. Kesehatan.

Berdasarkan hasil wawancara melalui sejumlah siswa diketahui bahwa siswa sering merasa lesu dan tidak konsentrasi ketika sedang membaca materi yang diberikan guru. Kelesuan muncul disebabkan oleh beberapa hal antara lain karena kebiasaan tidur larut malam. Akibat dari kebiasaan tersebut menyebabkan siswa menjadi kurang tidur dan pada akhirnya menimbulkan rasa ngantuk. Apa lagi sekarang pembelajaran melalui daring sehingga siswa semakin malas untuk mengikutinya. Kedua hal ini menyebabkan daya konsentrasi siswa dalam belajar menjadi berkurang. Munculnya kelesuan yang disebabkan oleh beberapa hal tersebut mengakibatkan terganggunya konsentrasi siswa dalam belajar sehingga siswa tidak dapat belajar sebagaimana semestinya. Dengan demikian terlihat bahwa kesehatan memang merupakan salah satu faktor yang sangat penting untuk menunjang kelancaran proses belajar. Slameto (2010:54), menyatakan bahwa sehat berarti dalam keadaan baik segenap badan beserta bagian-bagiannya/bebas dari penyakit. Dengan kondisi tubuh yang sehat seseorang dapat melakukan aktivitas belajar secara baik. Sebaliknya seseorang yang kesehatannya terganggu akan mudah merasa lelah, kurang semangat, mudah pusing, ngantuk jika badannya lemah ataupun ada gangguan-gangguan/kelainan-kelainan fungsi alat inderanya sehingga mengakibatkan terganggunya proses belajar. Anak yang kurang sehat dapat mengalami kesulitan belajar, sebab ia mudah capek, mengantuk, pusing, daya konsentrasinya hilang, kurang semangat, pikiran terganggu". Akibat dari terganggunya kesehatan inilah yang menyebabkan siswa sulit untuk memahami penjelasan dari guru karena terjadi gangguan pada aspek kognitifnya (Abu Ahmadi dan Widodo Supriyono, 2008:79).

b. Motivasi belajar.

Data yang dikumpulkan menunjukkan bahwa 8 siswa memiliki motivasi dalam belajar akuntansi sedangkan 12 siswa lainnya kurang memiliki motivasi. Dengan demikian dapat simpulkan bahwa lebih banyak siswa yang kurang memiliki motivasi dalam belajar dari pada yang memiliki motivasi. Penyebab termotivasinya siswa dalam belajar akuntansi antara lain karena menyukai guru yang mengajar, berkaitan dengan cita-cita siswa, dan menganggap akuntansi sebagai pelajaran yang menantang sehingga siswa menjadi semakin ingin mempelajarinya. Sedangkan penyebab kurang termotivasinya siswa dalam belajar, disebabkan oleh dua hal, yaitu karena ketidaksukaan terhadap pelajaran akuntansi dan ketidaksukaan terhadap pengajaran yang diberikan oleh guru. Ketidaksukaan terhadap pelajaran dan pengajaran membuat siswa menjadi tidak bersemangat dalam belajar materi persamaan dasar akuntansi. . Oleh sebab itu dorongan dari luar dirinya yang merupakan motivasi ekstrinsik sangat diharapkan agar siswa dapat belajar dengan baik. Slameto (2010:58), menyatakan bahwa dalam proses belajar haruslah diperhatikan apa yang dapat mendorong siswa agar dapat belajar dengan baik atau padanya tumbuh motif untuk berpikir dan memusatkan perhatiannya. Maka dalam hal ini guru bertugas untuk memberikan motivasi kepada siswanya supaya ia mau belajar karena guru memilki peranan strategis dalam menumbuhkan motivasi belajar peserta didiknya melalui berbagai aktivitas belajar yang didasarkan pada pengalaman dan kemampuan guru kepada siswa secara individu. Selain guru, orang tua juga sangat berperan aktif dalam menumbuhkan belajar siswa dirumah.

c. Minat belajar.

Bahwa minat siswa terhadap pembelajaran akuntansi rendah. Hal ini terlihat dari banyaknya siswa yang tidak menyukai pembelajaran akuntansi, yaitu dari 34 siswa, ada 14 orang yang tidak suka dengan nilai dibawah KKM. Ketidaksukaan siswa 
terhadap pembelajaran akuntansi disebabkan oleh beberapa hal, yang pertama adalah berkaitan dengan materi pengajaran dari guru. Ketika suasana yang dirasakan sedang tidak baik maka akan membuat siswa menjadi kurang menyukai apa yang sedang dipelajari atau sebaliknya. Dan hal terakhir yang mempengaruhi minat siswa dalam belajar pembelajaran akuntansi, yaitu berkaitan dengan pemahaman siswa. Beberapa siswa mengatakan bahwa mereka tidak menyukai pembelajaran akuntansi karena menganggap akuntansi sebagai pelajaran yang rumit.

d. Sikap terhadap belajar

Hasil penelitian menunjukkan bahwa siswa yang pernah absen mengikuti pembelajaran yang disebabkan berhalangan mengikuti pembelajaran karena sakit atau ijin. Ada juga yang pada saat pembelajaran membantu orang tua di sawah, bermain handpone untuk facebomain game online, SMS serta mendengarkan musik melalui handset. Beberapa sikap tersebut muncul ketika siswa sedang merasa malas, bosan terhadap penjelasan materi yang disampaikan oleh guru dan juga disebabkan karena ketidaksukaan terhadap pelajaran. Hasil penelitian menunjukkan bahwa perhatian belajar siswa dipengaruhi oleh beberapa hal antara lain berkaitan dengan pemahaman, pengajaran serta suasana yang dirasakan oleh siswa. Siswa akan memperhatikan penjelasan dari guru apabila mereka dapat memahami materi yang disampaikan, suasana hatinya sedang dalam keadaan baik, dan pengajaran yang diberikan dapat membuat siswa menjadi senang sehingga menyebabkan siswa menjadi serius dalam memperhatikan.Sebaliknya, ketika siswa tidak dapat memahami materi yang disampaikan, suasana hatinya sedang dalam keadaan buruk dan pengajaran yang diberikan dirasa tidak menyenangkan, maka siswa akan bersikap acuh terhadap penjelasan materi yang disampaikan oleh guru. Hal lainnya yang masih berkaitan dengan sikap terhadap belajar, yaitu siswa yang malas untuk membaca buku pelajaran, serta malas untuk bertanya kepada guru mengenai hal-hal yang belum dimengerti.

e. Cara Guru Mengajar

Berdasarkan hasil wawancara dengan siswa, diketahui bahwa ada beberapa siswa yang menyukai cara guru dalam mengajar dan ada pula yang tidak suka. Ketidaksukaan siswa terhadap cara guru mengajar disebabkan karena penjelasan yang disampaikan guru sulit untuk dipahami, selain itu ketika mengajar suara dari guru yang bersangkutan terlalu pelan sehingga siswa menjadi kurang jelas dalam mendengarkan materi yang disampaikan dan yang terakhir ketika mengajar guru cenderung tidak memperhatikan siswa secara merata. Sedangkan yang membuat siswa menyukai cara mengajar guru adalah karena guru tersebut sabar dalam menghadapi murid-muridnya serta santai ketika mengajar.

f. Kurangnya sumber (Buku pelajaran)

Mengenai sumber belajar yang digunakan untuk mendukung proses pembelajaran akuntansi, khususnya tentang buku pelajaran diketahui bahwa siswa tidak memiliki buku pegangan baik berupa buku paket maupun lembar kerja siswa (LKS). Ketika proses belajar berlangsung siswa hanya mengandalkan catata-catatan yang diberikan oleh guru.

\section{Pembahasan}

1. Kesulitan yang dihadapi dalam menganalisis transaksi

Berdasarkan hasil wawancara yang telah dilakukan terhadap siswa diketahui bahwa yang menjadi kendala bagi siswa ketika menganalisis transaksi pada materi persamaan dasar akuntansi terdiri atas dua kendala, yaitu siswa sulit untuk menentukan akun dan sering salah dalam menetukan jumlah nominal dari akun yang dimaksud. Kedua hal ini pada akhirnya menyebabkan hasil yang diperoleh dari 
persamaan dasar akuntansi menjadi tidak seimbang. Sesuai dengan pendapat Agung Feryanto dkk (2012:20), menyatakan bahwa persamaan akuntansi merupakan dasar pencatatan akuntansi dengan sistem berpasangan. Oleh sebab itu, kedua sisi yang saling berpasangan harus seimbang dalam menunjukkan setiap transaksi yang terjadi beserta perubahannya. Dengan demikian apabila hasil dari persamaan dasar akuntansi tidak seimbang, maka dapat disimpulkan bahwa pekerjaan siswa dalam menyelesaikan soal persamaan dasar akuntansi tersebut salah. Berdasarkan hasil temuan di atas dapat disimpulkan bahwa siswa mengalami kesulitan belajar pada pokok bahasan akuntansi karena kurangnya pemahaman terhadap materi yang dijelaskan sehingga menyebabkan hasil belajar yang diperoleh menjadi tidak dapat mencapai kriteria ketuntansan minimal yang telah ditetapkan oleh sekolah, yaitu 70 . Hal tersebut sesuai dengan pendapat Abin Syamsuddin Makmun (2012:308), yang menyatakan bahwa seseorang diduga mengalami kesulitan belajar kalau yang bersangkutan tidak mencapai taraf kualifikasi hasil belajar tertentu.

2. Faktor-faktor yang mempengaruhi kesulitan belajar siswa pada materi persamaan dasar akuntansi

a. Kesehatan

Berdasarkan hasil wawancara yang berkaitan dengan faktor kesehatan diketahui bahwa siswa sering merasa lesu ketika guru menjelaskan materi di depan kelas. Kelesuan terjadi ketika kondisi siswa sedang mengalami penurunan yang disebabkan karena kurang tidur, adanya kegiatan di luar aktivitas belajar dan juga disebabkan oleh waktu belajar yang berada pada jam terakhir. Munculnya kelesuan yang disebabkan oleh beberapa hal tersebut mengakibatkan terganggunya konsentrasi siswa dalam belajar sehingga siswa tidak dapat belajar sebagaimana semestinya. Dengan demikian terlihat bahwa kesehatan memang merupakan salah satu faktor yang sangat penting untuk menunjang kelancaran proses belajar. Slameto (2010:54), menyatakan bahwa sehat berarti dalam keadaan baik segenap badan beserta bagian-bagiannya/bebas dari penyakit. Dengan kondisi tubuh yang sehat seseorang dapat melakukan aktivitas belajar secara baik. Sebaliknya seseorang yang kesehatannya terganggu akan mudah merasa lelah, kurang semangat, mudah pusing, ngantuk jika badannya lemah ataupun ada gangguan-gangguan/kelainan-kelainan fungsi alat inderanya sehingga mengakibatkan terganggunya proses belajar. Anak yang kurang sehat dapat mengalami kesulitan belajar, sebab ia mudah capek, mengantuk, pusing, daya konsentrasinya hilang, kurang semangat, pikiran terganggu". Akibat dari terganggunya kesehatan inilah yang menyebabkan siswa sulit untuk memahami penjelasan dari guru karena terjadi gangguan pada aspek kognitifnya (Abu Ahmadi dan Widodo Supriyono, 2008:79).

\section{b. Motivasi belajar.}

Berdasarkan penelitian yang telah dilakukan berkaitan dengan motivasi belajar menunjukkan bahwa lebih banyak siswa yang kurang memiliki motivasi dalam belajar dari pada yang memiliki motivasi. Kurang termotivasinya siswa dalam belajar, disebabkan oleh ketidaksukaan terhadap pelajaran akuntansi dan ketidaksukaan terhadap pengajaran yang diberikan oleh guru. Ketidaksukaan terhadap pelajaran dan pengajaran membuat siswa menjadi tidak bersemangat dalam belajar materi persamaan dasar akuntansi. Oleh sebab itu dorongan dari luar dirinya yang merupakan motivasi ekstrinsik sangat diharapkan agar siswa dapat belajar dengan baik. Slameto (2010:58), menyatakan bahwa dalam proses belajar haruslah diperhatikan apa yang dapat mendorong siswa agar dapat belajar dengan baik atau padanya tumbuh motif untuk berpikir dan memusatkan perhatiannya. Maka dalam hal ini guru bertugas untuk memberikan motivasi kepada siswanya 
supaya ia mau belajar karena guru memilki peranan strategis dalam menumbuhkan motivasi belajar peserta didiknya melalui berbagai aktivitas belajar yang didasarkan pada pengalaman dan kemampuan guru kepada siswa secara individu. Selain guru, orang tua juga sangat berperan aktif dalam menumbuhkan belajar siswa dirumah.

c. Sikap terhadap belajar

Hasil penelitian menunjukkan bahwa sikap siswa dalam belajar masih kurang baik ini terlihat dari sikap buruk yang diperlihatkan ketika mengikuti proses belajar secara daring sering tidak mengikuti, malas membaca buku pelajaran dan malas bertanya. Dari beberapa masalah yang dijabarkan di atas berkaitan dengan sikap belajar siswa dapat disimpulkan bahwa siswa kurang bersungguhsungguh dalam belajar. Sikap terhadap belajar juga nampak dari kesungguhan mengikuti pelajaran, atau sebaliknya bersikap acuh terhadap aktivitas belajar (Aunnrrahman, 2012:180). Akibat dari sikap belajar yang kurang baik membuat siswa menjadi kurang dapat memahami pembelajaran secara baik karena banyak melewatkan penjelasan dari guru sehingga munimbulkan kesulitan dalam belajar bagi diri mereka. Oleh sebab itu seorang pengajar harus dapat menarik perhatian siswa dalam kegiatan belajar mengajar, sebab dengan perhatian yang dimiliki siswa akan timbul keinginan yang tertuju pada suatu hal tertentu.

d. Cara guru mengajar

Berdasarkan hasil wawancara dengan siswa, diketahui bahwa ada beberapa siswa yang tidak menyukai cara guru mengajar. Ketidaksukaan siswa terhadap cara guru mengajar disebabkan karena materi yang diberikan sukar untuk dipahami. Oleh sebab itu diharapkan kepada guru untuk selalu mengevaluasi caranya dalam mengajar karena hal tersebut merupakan penentu keberhasilan proses belajar mengajar. Cara guru mengajar yang baik adalah dengan mengetahui secara jelas obyek pengajaran. Jika pengajaran jelas sasarannya maka akan membuat murid bisa melihat dengan jelas maksud dari pokok pelajaran tersebut. Murid dapat menangkap semua pelajaran, bahkan mereka dapat mengalami kemajuan didalam belajar.

a. Kurangnya sumber (buku pelajaran)

Pada penelitian ini salah satu faktor yang dijadikan sebagai indikator penelitian adalah mengenai kurangnya sumber belajar yang dikhususkan pada buku pelajaran. Kurangnya sumber buku pelajaran juga dapat mempengaruhi kegiatan belajar karena akibat kurangnya buku pelajaran maka pengetahuan siswa terhadap materi pelajaran menjadi terbatas. Diketahui bahwa dalam mengikuti kegiatan pembelajaran siswa hanya mengandalkan catatan-catatan yang diberikan oleh guru. Siswa tidak memiliki buku pegangan baik berupa buku paket maupun lembar kerja siswa ( LKS). Yang menjadi faktor utama mengapa guru tidak mewajibkan siswa untuk tidak memilki buku paket maupun LKS adalah karena berkaitan dengan faktor ekonomi siswa yamg masih kurang.

\section{KESIMPULAN}

Berdasarkan hasil penelitian dan pembahasan, disimpulkan bahwa kesulitan yang sering dihadapi siswa dalam menganalisis transaksi pada materi persamaan dasar akuntansi terdiri dari dua kesuiltan antara lain, yang pertama siswa sulit dalam menentukan aku-akun yang dimaksud dalam transakis dan yang kedua adalah kesulitan dalam menentukan jumlah nominal dari akun yang dimaksud. Faktor-faktor yang menyebabkan kesulitan belajar pada materi persamaan dasar akuntansi yaitu terdiri dari faktor internal dan faktor eksternal antara lain (1) terganggunya kesehatan siswa ketikabelajar yang disebabkan oleh tiga hal, yaitu karena kurang 
tidur, lelah, serta waktu belajar yang kurang tepat (2) motivasi belajar masih rendah. Tidak termotivasinya siswa dalam belajar disebabkan oleh ketidaksukaan terhadap pembelajaran dan ketidaksukaan terhadap pengajaran yang diberikan oleh guru, (3) minat belajar siswa terhadap pembelajaran akuntansi tergolong rendah. Rendahnya minat siswa terlihat dari banyaknya siswa yang tidak menyukai pembelajaran akuntansi yang disebabkan oleh pengajaran, suasana dan pemahaman, (4) sikap yang ditunjukkan siswa ketika belajar masih kurang baik. Hal ini terlihat dari seringnya siswa menunjukkan sikap-sikap yang tidak sepatutnya dilakukan ketika belajar, (5) cara mengajar guru dianggap kurang menyenangkan, sehingga membuat siswa menjadi kurang mnyukai pengajaran yang diberikan oleh guru, (6) sumber belajar (buku pelajaran) masih minim khusunya bagi siswa yang hanya mengandalkan catatan yang diberikan oleh guru. Adapun usaha-usaha yang dapat dilakukan oleh guru untuk mengatasi kesulitan belajar siswa dalam mempelajari materi persamaan dasar akuntansi adalah dengan cara memotivasi siswa yang dapat dilakukan dengan berbagai cara seperti memberikan nilai, pujian, hadiah, ulangan, adanya kompetisi dan hukuman, berupaya untuk menumbuhkan minat siswa terhadap pelajaran yang dipelajari, memberikan evaluasi pada setiap pembelajaran dan mengadakan remedial pada siswa yang tidak mencapai KKM, menyuruh siswa agar lebih rajin dalam membaca dan mengulang kembali materi tersebut dirumah.

\section{DAFTAR PUSTAKA}

Abin Syamsuddin Makmun. (2012). Psikologi Pendidikan Perangkat Sistem Pengajaran Modul. Bandung: PT Remaja Rosdakarya.

Abu Ahmadi dan Widodo Supriyono. (2008). Psikologi Belajar. Jakarta: PT. Rineka Cipta.

Agung Feryanto dkk. (2012). Lembar Kerja Siswa Ekonomi Progrm Ilmu Pengetahuan Sosial. Klaten: Intan Pariwara

Al Haryono Jusup. (2011). Dasar-dasar Akuntansi. Yogyakarta: STIE YKPN.

Aunnurrahman. (2012). Belajar dan Pembelajaran. Bandung.

Alfabeta. Hasbullah. (2012). Dasar-dasar Pendidikan. Jakarta: PT Raja Grafindo Persada

Lexy J. Moleong. (2013). Metodelogi Penelitian Kualitatif. Bandung: PT Remaka Rosdakarya.

Mubarok, Yoga and Drs. Sudarto HS.,MM (2018).. Analisis Kesulitan Belajar Persamaan Dasar Akuntasi Ditinjau Dari Sikap Siswa Tentang Metode Mengajar Guru Dan Pola Komunikasi Di SMK Batik 1 Surakarta Tahun Ajaran 2017/2018Skripsi Thesis, Universitas Muhamadiyah Surakarta.

Sumarti Dewiyani. (2012). Analisis Kesulitan Belajar siswa Paada Mata Pelajaran Akuntansi Kelas XI Di SMA Mujahidin. Pontianak: FKIP Untan.

Syaiful Bahri Djamarah. (2011). Psikologi Belajar. Jakarta: PT Rineka Cipta. 